\title{
Üremik Kaşıntıda Kullanılan Tamamlayıcı Sağlık Yaklaşımları
}

\section{Complementary Health Approaches Used in \\ Uremic Pruritus}

\author{
Ayșe ŞAHIN' ${ }^{1}$, Seyhan ÇITLIK SARITAȘ ${ }^{2}$, Ayșe SOYLU ${ }^{3}$
}

${ }^{I}$ Öğretim Görevlisi, Harran Üniversitesi Viranşehir Sağllk Yüksekokulu Hemşirelik Bölümü, Şanlıurfa, Türkiye. ${ }^{2}$ Dr. Öğr. Üyesi, İnönü Üniversitesi Hemşirelik Fakültesi İ̧̧ Hastalıkları Hemşireliği Anabilim Dalı, Malatya, Türkiye.

${ }^{3}$ Öğretim Görevlisi, Kahramanmaraş Sütçü İmam Üniversitesi Sağlk Hizmetleri Meslek Yüksekokulu, Kahramanmaraş, Türkiye.

Geliș Tarihi: 24 Nisan 2020

Kabul Tarihi: 21 Mayss 2020

\section{İletişim / Correspondence:}

Ayşe ŞAHIN

E-posta: sahinayse.2702@gmail.com

\section{Özet}

Kronik böbrek yetmezliği hastaları tanı konulmasından itibaren birçok çıkış noktası aramakta ve tamamlayıcı yaklaşım yöntemlerine başvurmaktadır. Bilimsel kanıtların azlığına rağmen, tamamlayıcı sağlık yaklaşımları, hastalığı önlemek, konvansiyonel tıbbın olumsuz etkilerine karşı koymak ve bütüncül bakımı sağlamak için yaygın olarak kullanılmaktadır. Üremik kaşıntısı olan hastaların ise diyet, mentol içeren bitkisel ilaçlar, masaj, hipnoz, hayal kurma, sosyal destek gruplarına katılım, düzenli egzersiz, gevşeme egzersizleri, soğuk uygulama, aromaterapi, termalterapi, hidroterapi, akupunktur ve akupressure gibi uygulamalara başvurdukları saptanmıştır. Kronik böbrek yetmezliği hastalarında böbrek boşaltım fonksiyonunun olmaması nedeniyle tamamlayıcı sağlık yaklaşımlarının kullanılması tehlikeli olabilir. Bu nedenle, hemşireler tamamlayıcı sağlık yaklaşımlarının hastanın sağlık durumu üzerindeki etkilerini bilmeli, ek bilgi, beceri ve uzmanlık gerektiğinde bunu değerlendirebilmelidir.

Anahtar Kelimeler: Kronik Böbrek Yetmezliği; Üremik Kaşıntı; Tamamlayıcı Sağlık Yaklaşımları.

\begin{abstract}
Patients with chronic kidney failure are looking for many starting points since diagnosis and resort to complementary methods. Despite the lack of scientific evidence, complementary health approach methods are widely used to prevent disease and to protect against the negative effects of conventional medicine and provide holistic protection. Uremic pruritus individuals were found to apply to applications such as diet, herbal medicines containing menthol, massage, hypnosis, imagination, participation in social support groups, regular exercise, relaxation exercises, cold application, aromatherapy, thermal therapy, hydrotherapy, acupuncture, and acupressure. The use of complementary health approaches can be dangerous due to the lack of renal excretory function in CRF patients. Therefore, nurses should be able to evaluate the effects of complementary health approaches on the patient's state of health and accept this when additional knowledge, skills, and expertise are required.
\end{abstract}

Keywords: Chronic Renal Failure; Uremic Pruritus; Complementary Health Approaches. 


\section{GİRIŞ}

Kronik böbrek hastalığ 1 (KBH), dünyada ve ülkemizde epidemi halini almış önemli bir halk sağlı̆̆1 sorunudur. Kronik böbrek yetmezliği (KBY), çeșitli hastalıklara bağlı olarak gelișen kronik, ilerleyici ve geri dönüșsüz nefron kaybı ile karakterize morbidite, mortalite ve sağlık harcamalarını arttıran ve yaşam kalitesini azaltan, önemli bir nefrolojik sendromdur. Kronik böbrek yetmezliği, en az üç ay boyunca böbrek hasarı varlığı veya glomerüler filtrasyon hızının (GFR) $60 \mathrm{~mL} /$ dak / $1.73 \mathrm{~m}^{2}$ den düşük olması şeklinde de tanımlanır $(1,2,3)$. KBY hastaları tanı konulmasından itibaren birçok çıkış noktası aramakta ve tamamlayıcı yöntemlere başvurmaktadır (4). Bilimsel kanıtların azlığına rağmen, tamamlayıcı sağlık yaklaşımı (TSY) yöntemleri, hastalığın önlenmesi ve konvansiyonel tıbbın olumsuz etkilerine karşı koymak ve bütüncül bakımı sağlamak için yaygın olarak kullanılmaktadır (5). KBY hastaları da hastalık semptomlarını gidermek, yaşamı tehdit eden durumlarda hastalığın kontrolünü sağlamak, standart tıbbi tedavilerine destek olmak, immün sistemlerini güçlendirmek, fiziksel, bilişsel, duygusal, sosyal ve ruhsal yönden kendini iyi hissetmek, diyalize girmeyi geciktirmek, böbreği korumak, diyalizdeki yaşam kalitesini arttırmak ve ölüm korkusunu yenmek için tamamlayıcı yaklaşımlara başvurmaktadır (4).

Yapılan çalışmalara bakıldığında dünya genelinde TSY yöntemlerinin kullanım prevalansının \%9.8 ile \%76 arasında değiştiği, Amerika Birleşik Devletleri'nde (ABD) yetişkinlerin $\% 38$ 'inin, İngiltere'de \%51.8'inin, Avustralya'da ise \% 68.9'unun TSY yöntemlerini kullandıkları belirtilmektedir $(6,7,8)$. Diyaliz tedavisi alan hastalar ise hastalık veya tedaviden kaynaklanan komorbidite semptomlarını hafifletebileceğini düşündükleri için $\% 57$ ile $\% 64.4$ oranında TAT yöntemlerini kullanmayı tercih ettiklerini belirtmişlerdir $(6,9,10)$. Ulusal Tamamlayıcı ve Bütünleştirici Sağlık Merkezi (NCCIH) tamamlayıcı sağlık yaklaşımlarını, doğal ürünler, zihin ve beden uygulamaları ile diğer tamamlayıcı sağlık yaklaşımları olarak aşağıdaki gibi sınıflandırmıştır.

\section{Doğal ürünler}

- Bitkiler, vitaminler ve mineraller ve probiyotikler gibi ürünleri içerir.

\section{Zihin ve Beden Uygulamaları}

- Yoga, kiropraktik ve osteopatik manipülasyon, meditasyon, akupunktur, gevşeme teknikleri, tai chi, qi gong, hipnoterapi gibi uygulamaları içerir.

\section{Diğer Tamamlayıcı Sağlık Yaklaşımları}

- Ayurveda tıbbı, geleneksel Çin tıbbı, homeopati, naturopati ve fonksiyonel tıp uygulamalarıdır.

\section{Böbrek Yetmezliği ve Üremik Kaşıntı}

Üremik kaşıntı, diyalize giren son dönem böbrek hastalığ ve yaşam kalitesini azaltan bir semptomdur. Diyaliz tedavilerindeki gelişmeler göz önüne alındığında kronik böbrek yetmezliğine bağlı kaşıntı insidansının geçmiş yıllara göre azaldığı, ancak yapılan son araştırmalara bakıldığında diyalize giren hastalarda $\% 22$ ila $\% 84$ oranında kaşıntı olduğu belirlenmiştir $(12,13)$. Üremik kaşıntının patogenezinin belirsizliği nedeniyle sınırlı terapötik yöntemlerin kullanımı, kaşıntı kontrolünü sağlamada yetersiz kalmaktadır. Yapılan araştırmalara bakıldığında üremik kaşıntı tedavisindeki en son yaklaşımlar; nemlendiriciler, ultraviyole 1şınlama, enflamatuvar bileşikler ve oral antihistaminikler gibi topikal ürünlerin uygulanmasinı veya anti-enflamatuar etki gösteren ilaçlarla yapılan sistemik tedavilerdir. Ancak bu yöntemlerin etkileri genellikle geçicidir veya yan etkileri bulunmaktadır. Antihistaminikler akut kaşıntıyı hafifletebilir, ancak kronik kaşıntıyı azaltmazlar ve uzun süreli kullanımları, kuru ve atrofik cilt gibi yan etkilere neden olabilmektedir $(14,15,16)$. Bu nedenle hastalar, üremik kaşıntının tedavisinde birbirinden çok farklı farmakolojik tedaviler ile birlikte TSY yöntemlerini kullanmaktadır $(4,17)$.

KBY hastaları sıklıkla hipertansiyon, yorgunluk, konstipasyon, bacak ödemi, ağrı, kramplar, anksiyete, depresyon, uyku bozuklukları, kaşıntı gibi semptomlarla baş edebilmek, böbrek hastalığının ilerlemesini durdurmak ve yaşam 
kalitelerini artırmak için bitkisel ürünler ve gıda takviyeleri, akupres, akupunktur, homeopati, egzersiz, aromaterapi, yoga ve refleksoloji gibi TSY yöntemlerine başvurmaktadırlar. Üremik kaşıntılı bireylerin ise diyet, mentol içeren bitkisel ilaçlar, masaj, hipnoz, hayal kurma, sosyal destek gruplarına katılım, düzenli egzersiz, gevşeme egzersizleri, soğuk uygulama, aromaterapi, termalterapi, hidroterapi, akupunktur ve akupressure gibi uygulamalara başvurdukları saptanmıştır. Yapılan çalışmalarda TSY'nın tek başına ya da farmakolojik yöntemlerle birlikte kullanılmasının böbrek yetmezliğine bağlı üremik kaşıntının kontrolünde etkili olduğu gösterilmiştir $(6,17)$.

\section{Üremik Kaşıntıda Kullanılan Tamamlayıcı Sağlık Yaklaşımları}

\section{Akupunktur}

Çin'de 3000 yıldan fazla süredir uygulanmakta olan akupunktur, stratejik vücut bölgelerine ince iğnelerin terapötik olarak yerleştirilmesini ve manipülasyonunu içeren geleneksel tedavi yöntemlerinden biridir $(18,19)$. Akupunkturun hemodiyalize giren hastalarda semptom yönetimi için uygun ve güvenli bir yöntem olduğu belirtilmektedir (20). Xiong ve ark.'nın (2018) kronik böbrek hastaları ile yaptıkları çalışmada akupunkturun üremik kaşıntı, uykusuzluk ve yorgunluk gibi hemodiyalizle ilgili birçok komplikasyonu kontrol ettiği, Che-yi ve ark.'nın (2005) üremik kaşıntısı olan hemodiyaliz hastaları ile yaptıkları randomize kontrollü çalışmada, akupunktur sonrası kaşıntı skorlarının düştüğü, akupunkturun üremik kaşıntı tedavisinde kolay, etkili ve güvenli bir yöntem olarak kullanılabileceği belirtilmiştir $(21,22)$. Yan ve ark. (2015) hemodiyaliz hastaları ile yaptıkları çalışmada akupunkturun hemodiyalizle ilişkili üremik kaşıntı sıklığını ve şiddetini azalttığını ve yaşam kalitesini arttırmada etkili olduğunu belirtmişlerdir. Sonuç olarak, akupunkturun kronik böbrek hastaları için faydalı olduğu ancak potansiyel mekanizmalarını doğrulamak için daha fazla araştırmaya ihtiyaç duyulduğu da belirtilmektedir $(21,23)$.

\section{Akupressure}

Akupressure, vücutta enerji taşıyan meridyenler üzerinde akupunktur noktalarına parmaklar, avuç içi, tenis topları veya özel stimülasyon cihazları ile belli bir düzeyde basınç uygulayarak yapılan masaj tekniğidir. Akupressure tedavisi, geleneksel Çin tıbbı tedavi yöntemidir ve akupunktur ile aynı amaca sahiptir. Akupressurenin amac1 vücuttaki enerji akışını sağlamak ve dengelemek, sağlığ1 korumak, geliştirmek ya da hastalığ önlemektir $(23,24,25)$. Akupressure için iğnesiz akupunktur da denilmektedir. Akupressure hastalıkların klinik yönetimi için yaygın olarak kullanılan basit, güvenli, acısız, ağrısız, kullanışl1, etkili, yan etkisi olmayan, uygun maliyete sahip ve iyi bir eğitimle kişinin kendisinin bile uygulayabileceği bir tedavi yöntemidir. Yapılan çalışmalarda akupressurenin, çeşitli hastalıklarda ve kronik böbrek hastalığı olanlarda ağrı tedavisi başta olmak üzere uykusuzluk, depresyon, yorgunluk, bulant1-kusma, kas krampları ve kaşıntı gibi birçok semptomun kontrolünde etkili olduğu görülmektedir $(17,23,25,26)$. Yan ve ark.'nın (2015) yaptığ hastalarına, altı hafta boyunca haftada üç kez kulaktan akupressure tedavisi uygulanmış ve uygulama sonrasında hastaların üremik kaşıntı puan ortalamalarının düştüğü ve yaşam kalitelerinin arttığ nöz elektriksel sinir stimülasyonu (TENS) akupunktur cihazı kullanılarak, akupunktur noktalarına akupressure uyguladıkları çalışmada hemodiyaliz ile ilişkili üremik kaşıntı sıklığ 1 ve şiddetini azaltmada etkili olduğu; Jedras ve ark.'nın (2003) diyaliz hastaları ile yaptıkları çalışmada ise 15 seans boyunca haftada üç kez akupressure uygulaması sonrası kaşıntı skorlarında anlamlı değişiklik olduğu, bunun sonucunda da akupressurenin üremik kaşıntıyı azaltmada etkili olduğu sonucuna varılmıştır $(23,27,28)$.

\section{Aromaterapi}

Aromaterapi, fiziksel ve psikolojik iyilik sağlamak için bitkisel kaynaklardan (yapraklar, çiçekler, meyveler, ağaç kabukları, kökler) çıkarılarak konsantre edilmiş esansiyel yağların terapötik olarak organizmayı etkilemesi üzerine kurulan tedavi şeklidir. Aromaterapi, bireylerin zihnini, bedenini ve ruhunu tedavi etmenin doğal bir yoludur $(29,30)$. Esansiyel yağlar düşük dozlarda, masaj için ya da çevreye güzel koku sağlamak amacıyla kullanılabilmektedir. Melisa, okaliptüs, lavanta, limon, kekik, karanfil, lavanta çiçeği, çay ağac1, tatlı badem, jojoba, chia ve yasemin gibi 
tedavi edici yağlar, kaşıntının algılanmasında ve iletilmesinde azalma, gevşeme ve rahatlama sağlamak amacıyla kullanılmaktadır (24). KBY hastalarında aromaterapinin uygulandığı çalıșmalar incelendiğinde; Shahgholian ve ark.'nın (2010) diyalize giren hastalarla yaptıkları çalışmada hastalara beş hafta boyunca lavanta, nane ve çay ağacı yağından oluşan karışımla, aromaterapi masajı uygulaması sonucu hastalardaki kaşıntının önemli ölçüde hafiflediği; Jeong ve ark.'nın (2010) yaptığı çalışmada son dönem böbrek yetmezliği bulunan hastalara sekiz hafta boyunca topikal olarak uyguladıkları chia tohumu yağınının cilt hidrasyonunu sağladığı ve kaşıntıda etkili olduğu $(31,32)$; bir diğer deneysel çalışmada ise hemodiyaliz hastalarına, lavanta ve çay ağacı yağı kullanarak altı hafta boyunca aromaterapi uygulamasi sonucu deney grubundaki hastaların kaşıntı puanının, kontrol grubundaki hastaların kaşıntı puan ortalamalarına göre daha düşük olduğu ve gruplar arasındaki farkın istatistiksel yönden anlamlı olduğu bildirilmiştir (33). Hemodiyaliz uygulanan hastalarda komplikasyonları yönetmenin ağır maliyetleri düşünüldüğünde, aromaterapinin hemodiyaliz hastalarındaki komplikasyonları ve kaşıntıyı azaltmak için ucuz, hızlı ve etkili bir tedavi olarak kullanılabileceği görülmektedir (30).

\section{Bitkisel Ürünler}

Bitkisel ürünler tarih boyunca hastalıkları önlemek ve tedavi etmek amacıyla kullanılmıştır. Fitoterapi, (phytos=bitki, therapy=tedavi) bitkisel tedavi anlamında kullanılır. Bitkisel tedavinin tarihi insan varlığ 1 kadar eskilere dayanmakla birlikte günümüzde kullanılan bitkisel tedavinin kökeni Çin ve Hindistan'a dayanmaktadır. Bitkisel tedavi, TSY yöntemleri arasında yer almakta ve birçok dermatolojik hastalıkların tedavisinde yaygın olarak kullanılmaktadır. Dünya Sağlık Örgütü, dünya nüfusunun yaklaşık olarak \%80'inin kullandığ 1 ilaçların zaten bitkisel kaynaklı olduğunu belirtmektedir $(24,34)$. Hastaların çoğu konvansiyel tıp tedavileri ile başarı sağlanamadığı zaman, yan etkisinin daha az olduğunu düşünerek bitkisel tedaviyi tercih etmektedir. KBY gibi kronik veya tamamen tedavi edilemeyen bir sağlık sorunu olan hastalar ise hipertansiyon, uykusuzluk, kas krampları gibi bazı semptomları gidermek için "doğal" çareler olarak düşündükleri bitkisel ürünlere başvurabil- mektedirler $(34,35,36)$. Dermatolojide yulaf ezmesi, 1sırgan, yüksükotu, hatmi çiçeği, dut, çemen, ceviz yaprağı, lavanta, meşe, menekşe, papatya, aloe vera ve kaygan karaağacin kaşıntının topikal tedavisinde yararlı olduğu görülmüştür (24). Mentol, eski çağlardan beri tıbbi amaçlar için kullanılan, doğal olarak oluşan, bitkisel kaynaklı bir maddedir. Dermatolojide topikal kaşıntıda, antiseptik, analjezik ve soğutma amacıyla sıklıkla kullanılmaktadır. Mentolün çeşitli şekillerde kullanımı da deri veya mukozada serinlik hissi uyandırdığ 1 ve üremik kaşıntılı hastalarda cilt üzerinden algılanan ağrı ve kaşıntı gibi duyuların iletilmesini engellediği belirtilmektedir (37). Bromma ve ark.'nın (1995) yaptığı çalışmada mentol uygulamasının kaşıntıda azalma sağladığı, Milikan'ın (2003) yaptığı çalışmada geleneksel olarak yapılan yulaf ezmesi banyosunun kaşıntının topikal tedavisinde son derece yararlı olduğu, Patel ve ark.'nın (2007) çalışmasında ise mentolün çeşitli şekillerde kullanımının deri veya mukozada serinlik hissi uyandırdığı ve üremik kaşıntılı hastalarda cilt üzerinden algılanan ağrı ve kaşıntı gibi duyuların iletilmesini engellediği belirtilmektedir $(37,38$, 39).

Ancak KBY hastalarının, bitkisel ürünlerin bilinçsiz kullanımına bağlı olarak karşılaşabilecekleri sorunlar çok daha fazladır. Böbrek yetmezliği gelişen hastaların kullandıkları bitkisel ürünler, rezidüel böbrek fonksiyonları için zararlı olabilmektedir. Bu ürünler ilaçların etki mekanizmalarına benzer şekilde, direkt nefrotoksik etki gösterebilmekte veya glomerüler filtrasyon hızını azaltarak hemodinamik değişiklikler ile birlikte elektrolit dengesizlikleri, kan glikozu ve kan basincinda olumsuz etkilere neden olabilmektedir. Çünkü böbrek yetmezliği farmakolojik ajanların absorbsiyon, dağılım, metabolizma ve atılımını değiştirerek, farmakokinetiği etkilemektedir. Ayrıca bitkisel ürünlerin değişken, karmaşık bileșimleri ve birçok aktif madde içermeleri nedeniyle farmakokinetiğin doğru değerlendirilmesi güçtür. $\mathrm{Bu}$ nedenlerle böbrek yetmezliği gelişen hastalarda bitkisel ürünlerden zehirlenmeyi ve diğer olumsuz etkileri önleyebilmek için doz çok iyi ayarlanmalı, aktif veya toksik metabolit içeriğinden şüphelenilen ürünler, güçlü kanıtlar olmadan kullanılmamalıdır (36, 41). 


\section{Hidroterapi}

Suyun, kaplıca, banyo, içme suyu kaynakları ve daha farklı yöntemler aracılığıyla tedavi amaçlı kullanılmasına "hidroterapi", hastanın mineralli su içeren banyo veya havuzlarda tedavi edilmesine ise "Balneoterapi" denilmektedir. Balneoterapinin etki mekanizması tam olarak bilinmemektedir. Terapötik özelliklerinin kimyasal, termal, mekanik ve immünmodülatör etkilerine bağl1 olabileceği düşünülmektedir. Sicak uygulama, immün sistemi uyarmakta, stresi baskılayan hormonların üretimini sağlamakta, dolaşım ve sindirim sistemini uyarmakta, kan akımını arttırmakta ve kaslarda gevşeme sağlayarak ağriya karşı gelişen duyarlılı̆̆ 1 azaltmaktadır. Atopik dermatitin kuru fazında uygulanan banyo, nemlendirici uygulamak için deriyi hazırlayabilir. Kaplıca suyu kullanılarak yapılan balneoterapinin refraktör atopik dermatit vakalarında akut alevlenme semptomlarını kontrol ettiği bildirilmiştir $(42,43)$. Inoue ve ark.'nın (1999) yaptığı çalışmada kaplica suyu kullanılarak yapılan balneoterapinin refraktör atopik dermatit vakalarında akut alevlenme semptomlarını kontrol ettiği belirtilmiştir (44). Ayrıca bu tedavinin yan etkileri de bulunmamaktadır $(42,43)$.

\section{GEVŞEME/EGZERSIZLERI}

Progresif gevşeme egzersizi, vücuttaki büyük kas gruplarının istemli olarak kasılıp gevşetilerek, aradaki farkın hissedilmesidir. Gevşeme egzersizlerinin stresi, anksiyeteyi, kas gerginliğini azalttığı, uykuyu kolaylaştırdığı, baş etme gücünü arttırarak bireyin olumlu benlik algisını geliştirdiği ve bakım kalitesini artırarak yaşamı olumlu yönde etkilediği belirtilmektedir (45). Meditasyon, nefes egzersizleri, karşılıklı ya da kendi kendine konuşma gibi gerginliğin azaltılmasıyla kaşıntının algılanmasını azaltarak kaşıntı ve ağrıya olan toleransı artırır (46).

\section{HIPNOTERAPI}

Hipnoz; telkin yoluyla diğer bir kişinin bilinç ve farkındalık, vücut, hisler, duygular, düşünceler, hafiza veya davranışlarında değişiklik elde etmek üzere tasarlanmış veya bu sonucu ortaya çıkaran eylem veya prosedürlerden oluşan uygulama yöntemidir (47). Hipnozun bir başka özelliği de; hipnozu uygulayanın hipnotik yolla beynin duyusal mekanizmasına ve öğrenilmiş kayıtlarına ulaşmayı başarmasıdır (48). Hipnoz, eski çağlardan beri tıbbi ve dermatolojik problemleri tedavi etmek için kullanılan TSY yöntemlerinden biridir (49). Dermatolojide hipnozun tıbbi kullanımları arasında kaşıntıyı azaltmak, cilt bozukluklarının iyileşmesini sağlamak, cilt bozukluklarının psikosomatik yönlerini saptamak, sağlıklı davranışları arttırmak, stresi azaltmak, uzun süreli analjezi sağlamak ve ciltle ilgili bilişsel ve duygusal işlevleri yeniden yapılandırmak gibi köklü alışkanlıkları değiştirmek yer alır (50, 51). Rucklidge ve ark.'nın (2002) çalışmasında altı seans kendi kendine yapılan hipnoz terapisinin hastaların günlük kaşıntı şiddetinde ve kaşıntıya bağlı uyku bozukluğunun derecesinde önemli azalmalar sağladığı, Perczel ve ark.'nın (2016) çalışmasında 15 seans uygulanan hipnoterapinin kaşıntı, ağnı, uykusuzluk, aktivite, anksiyete ve duygusal durumda iyileşme sağladığı belirtilmiştir $(52,53)$.

\section{Müzik Terapi}

Müzikle tedavinin tarihi tıp tarihi kadar eskiye dayanmaktadır. Çünkü insanlar tedavi araçları ile müziği çoğu kez bir arada kullanmışlardır. Müzik terapi uygulamas1, hipofiz bezini uyararak endorfin salınımını arttırır. Vücudun doğal ağrı kesici ve ruhsal durum düzenleyici maddesi olan endorfinin salınımı sonucunda ağrı, anksiyete azalır ve algılama üzerine olumlu etki yapar. $\mathrm{Bu}$ nedenle kaşıntı ve buna bağlı anksiyeteyi azaltmak için müziğin kullanılabileceği düşünülmektedir. Müzik kişiyi hoşa gitmeyen kaşıntılı uyaranlardan uzaklaştırıp, endorfin salınımını artırarak ve gevşemeyi başlatarak tedaviye yardımcı olmaktadır (24). Burrai ve ark.'nın (2014) hemodiyaliz hastalarına uyguladıkları canlı saksafon müziği dinletisinin ağrı düzeyinde düşüş ve kaşıntı seviyelerinde iyileşme sağladığı, Demirtaş ve ark.'nın (2019) randomize kontrollü çalışmalarında ise müzik terapi uygulanan hastalarda kaşıntı yoğunluğunun nemlendirici uygulanan hastalara göre daha fazla azaldığ 1 belirlenmiştir $(54,55)$.

\section{Hemşirelik ve Tamamlayıcı Sağlık Yaklaşımları}

Hemşirelik uygulamalarının ve tamamlayıcı yaklaşımların temel felsefesi benzerdir. Her ikisinin ortak yönleri, bireye holistik açıdan yaklaşmaları, 
tedavi sırasında destekleyici rolde olmaları, sağlığın yükseltilmesine ve hastanın aktif rolde olmasına odaklanmalarıdır (56). Dünyada ve Türkiye'de KBY hastalarının TSY'nın kullanımına ilişkin veriler yetersizdir. Bunun en önemli nedeni, çoğu KBY hastasının sağlık ekibini bilgilendirmeden TSY yöntemlerini kullanmas1dır (57). KBY hastalarında böbrek boşaltım fonksiyonunun olmaması nedeniyle tamamlayıc1 sağlık yaklaşımlarının kullanılması tehlikeli olabilir. TSY ve özellikle bitkisel ürünlerin kullanımı toksisitenin artmasına, ilaç etkileşimlerinin daha fazla olmasına ve ölümcül elektrolit dengesizliklerine neden olabilir (58). $\mathrm{Bu}$ nedenle, hastalarla iyi iletişim kurulmalı, bu yöntemlerin zararları, yararları hakkında yeterli bilgi verilmeli, danışmanlık sağlanabilmeli ve hastalar bu yöntemlerin yararlı ve zararlı etkileri açısından izlenmelidir (59). Sonuç olarak hemşireler tamamlayıcı sağlık yaklaşımlarının hastanın sağlık durumu üzerindeki etkilerini bilmeli, ek bilgi, beceri ve uzmanlık gerektiğinde bunu değerlendirebilmelidir (56).

\section{Kaynaklar}

1. Süleymanlar G. Kronik Böbrek Hastalığı ve Yetmezliği: Tanımı, Evreleri ve Epidemiyolojisi. Turkiye Klinikleri J Int Med Sci. 2007; 3(38): 1-7.

2. Erbay E, Zengin O, Yıldırım B, Yıldırım T, Abudalal A. Kronik Böbrek Yetmezliği Hastalarının Kaygı Düzeyleri ve Başetme Tutumları. Hacettepe Üniversitesi Nefroloji Bilim Dalı Örneği. Turk Neph Dial Transpl. 2016; 25(1): 95-9. doi: 10.5262/tndt.2016.1001.11.

3. KDIGO 2012 Clinical Practice Guideline for the Evaluation and Management of Chronic Kidney Disease. 2013; 3: (1).

4. Ovayolu N, Ovayolu Ö, Güngörmüş Z, Karadağ G. Böbrek Yetmezliğinde Tamamlayıcı Tedaviler. Nefroloji Hemşireliği Dergisi. 2015; 10(1): 40-46.

5. Bahall M. Use of complementary and alternative medicine by patients with end-stage renal disease on haemodialysis in Trinidad: A descriptive study. BMC Complement Altern Med. 2017;17: 250. doi:10.1186/s12906-017-1755-7.

6. Erdoğan Z, Atik ÖD, Çınar S. Kronik Böbrek Yetmezliğinde Tamamlayıcı ve Alternatif Tıp Yöntemlerinin Kullanımı. Arşiv Kaynak Tarama Dergisi. Archives Medical Review Journal. 2014; 23(4): 773-90.

7. Harris PE, Cooper KL, Relton C, Thomas KJ. Prevalence of complementary and alternative medicine (CAM) use by the general population: a systematic review and update. Int J Clin Pract. 2012; 66: 924-39. doi.org/10.1111/j.17421241.2012.02945.x.

8. Xue CCL, Zhang AL, Lin V, Costa DC, David F. Complementary and Alternative Medicine Use in Australia: A National Population-Based Survey. The Journal of Alternative and Complementary Medicine. 2007; 13: 643-50.

9. Nowack R, Balle C, Birnkammer F, Koch W, Sessler R, et al. Complementary and Alternative Medications Consumed by Renal Patients in Southern Germany. Journal of Renal Nutrition. 2009; 19(3), 211-219. doi.org/10.1053/ j.jrn.2008.08.008.

10. Zyoud SH. Samah W. Al-Jabi, Sweileh WM, Tabeeb GH, Ayaseh NA, et al. Use of complementary and alternative medicines in haemodialysis patients: a cross-sectional study from Palestine. Complementary and Alternative Medicine. 2016; 16: 204. DOI 10.1186/s12906-016-1196-8.

11. https://www.nccih.nih.gov/health/complementary-alternative-or-integrative-health-whats-in-a-name Erişim tarihi: 07.05.2020

12. warna SS, Aziz K, Zubair T, Qadir N, Khan M. Pruritus Associated With Chronic Kidney Disease: A Comprehensive Literature Review Cureus. 2019; 11(7): E5256. doi: 10.7759/Cureus.5256.

13. Rehman IU, Chohan TA, Bukhsh A, Khan TM. Impact of Pruritus on Sleep Quality of Hemodialysis Patients: A Systematic Review and Meta-Analysis. Journals Medicina. 2019; 55(10): 699. doi: 10.3390/Medicina55100699.

14. Mettang T, Kremer AE. Uremic pruritus. Kidney Int. 2015; 87(4): 685-91.doi: 10.1038/ki.2013.454. doi.org/10.1038/ki.2013.454

15. Narita I, Iguchi S, Omori K, Gejyo F. Uremic pruritus in chronic hemodialysis patients. Journal of Nephrology. 2008; 21(2): $161-5$

16. Nahidi Y, Badiee S, Torabi S, Abbasi SZ, Nazemian F, et al. A Acupuncture Effect on Pruritus in Hemodialysis Patients: A Randomized Clinical Trial. Iran Red Crescent Med J. 2018; 20(10): E65521. doi: 10.5812/İrcmj.65521.

17. Akça KN, Taşcı S. Hemodiyaliz Hastalarında Üremik Kaşıntı ve Akupresör Uygulaması. Maltepe Üniversitesi Hemşirelik Bilim ve Sanatı Dergisi. 2011;(4):190-96.) 
18. Zhuang Y, Xing JJ, Li J, Zeng BY, Liang F. Chapter one - History of Acupuncture Research. International Review of Neurobiology. 2013; (111): 1-23. https://doi.org/10.1016/B978-0-12-411545-3.00001-8.

19. Ijaz N, Boon H. Evaluating the international standards gap for the use of acupuncture needles by physiotherapists and chiropractors: A policy analysis. PLoS One. 2019; 14(12): e0226601. doi.org/10.1371/Journal.Pone.0226601.

20. Kim HK, Kim HT, Kang WJ, Sul JU, Lee SM, et al. Acupuncture for Symptom Management in Hemodialysis Patients: A Prospective, Observational Pilot Study. The Journal of Alternative and Complementary Medicine. 2011; 17(8): 74148.

21. Xiong W, He FF, You YR, Xiong J, Wang MY, et al. Acupuncture Application in Chronic Kidney Disease and its Potential Mechanisms. The American Journal of Chinese Medicine. 2018; 46(6): 1169-118. doi.org/ $10.1142 / \mathrm{S} 0192415 \mathrm{X} 18500611$.

22. Che-Yi C, Wen YC, Tsung MK, Ching CH. Acupuncture in haemodialysis patients at the Quchi (LI11) acupoint for refractory uraemic pruritus. Nephrol Dial Transplant 2005; 20(9): 1912-1915. doi.org/10.1093/ndt/gfh955.)

23. Yan C, Yao WG, Bao YJ, Shi JX, Yu H, et al. Effect of Auricular Acupressure on Uremic Pruritus in Patients Receiving Hemodialysis Treatment: A Randomized Controlled Trial. Evidence-Based Complementary and Alternative Medicine. 2015; 8. https://doi.org/10.1155/2015/593196.

24. Akça KN, Taşçı S. Kaşıntı Kontrolünde Kullanılan Nonfarmakolojik Yöntemler. Taf Prev Med Bull. 2013; 12(3): 359364.

25. Cho YC, Tsay SL. The effect of acupressure with massage on fatigue and depression in patients with end-stage renal disease. The Journal of Nursing Research : JNR: 2004; 12(1): 51-59. DOI: 10.1097/01.jnr.0000387488.63438.9a.

26. Shariati A, Jahani S, Hooshmand M, Khalili N. The effect of acupressure on sleep quality in hemodialysis patients. Complementary Therapies in Medicine. 2012; 20(6): 417-423. doi.org/10.1016/j.ctim.2012.08.001.

27. Kılıç AN, Taşçı S, Karataş N. Effect of Acupressure on Patients in Turkey Receiving Hemodialysis Treatment for Uremic Pruritus. Altern Ther Health Med. 2013; 19(5): 12-8.

28. Jedras M, Bataa O, Gellert R, Ostratvski G, Wojtaszek E, et al. Acupresure in the Treatment of Üremic Pruritus, Dialysis \& Transplantation. 2003; 32(1): 257-65.

29. Şahin A, Dirgar E, Olgun N. Diyabet Yönetiminde Kullanılan Tamamlayıcı ve Alternatif Tedaviler. Diyabet, Obezite ve Hipertansiyonda Hemşirelik Forumu Dergisi. 2019; 11:(1): 32-26.

30. Bouya S, Ahmadidarehsima S, Badakhsh M, Balouchi A, Koochakzai M. Effect of aromatherapy interventions on hemodialysis complications: A systematic review. Complementary Therapies in Clinical Practice. 2018; (32): 130-138.

31. Shahgholian N, Dehghan M, Mortazavi M, Gholami F, Valiani M. Effect of aromatherapy on pruritus relief in hemodialysis patients. Iran J Nurs Midwifery Res. 2010; 15(4): 240-244.

32. Jeong KS, Park JH, Park DB, Kim H. Effectiveness of Topical Chia Seed Oil on Pruritus of End-Stage Renal Disease (ESRD) Patients Andhealthy Volunteers. Ann Dermatol. 2010; 22(2): 143-148. doi.org/10.5021/ad.2010.22.2.143.

33. Kavurmacı M, Tan M. Üremik Kaşıntı ve Aromaterapi Uygulaması. Gümüşhane Üniversitesi Sağlı Bilimleri Dergisi. 2014; 3(1): 674-682.

34. Durusoy Ç, Ulusal GB. Dermatolojide Bitkisel Tedavi-Fitoterapi. Herbal Therapy in Dermatology-Phytotherapy. Türk Dermatoloji Dergisi. 2007; (1): 47-50.

35. Yetkin H, Yüksel BP. Dermatolojide Bitkisel Tedavi. Türkderm. 2006; 40(2): 40-45.

36. Kara B. Kronik Böbrek Yetmezliğine Bitkisel Ürünlerin Etkisi. Gülhane Tıp Dergisi. 2006; (48): 189-193.

37. Patel T, Ishiuji Y, Yosipovitch G. Menthol: A refreshing look at this ancient compound. Journal of the American Academy of Dermatology. 2007; 57(5): 873-878

38. Bromma B, Scharein E, Darsow U, Ring J. Effects of menthol and cold on histamine-induced itch and skin reactions in man. Neurosci Lett. 1995; 187(3): 157-60. doi.org/10.1016/0304-3940(95)11362-Z

39. Millikan EL. Alternative therapy in pruritus. Dermatologic Therapy. 2003;16(2):175-80. doi.org/10.1046/j.15298019.2003.01626.x.) (40- Patel T, Ishiuji Y, Yosipovitch G. Menthol: A refreshing look at this ancient compound. Journal of the American Academy of Dermatology. 2007; 57(5): 873-878.)

40. Patel T, Ishiuji Y, Yosipovitch G. Menthol: A refreshing look at this ancient compound. Journal of the American Academy of Dermatology. 2007; 57(5): 873-878.

41. Naomi V. Dahl. Alternative Medicine and Nephrology Series Editor: Naomi V. Dahl: Herbs and Supplements in Dialysis Patients: Panacea or Poison? Seminars in Dialysis: 2001:14(3).186-19.

42. Yaraşır E, Pirinçci E, Deveci ES. Bel Ağrısında Tamamlayıcı ve Alternatif Tedavi. Arşiv Kaynak Tarama Dergisi. Archives Medical Review Journal. 2018; 27(1): 93-108).

43. Karaca Ş, Kulaç M, Özel H, Kavuncu V. Dermatolojide Balneo-Foto-Terapi. Kocatepe Tıp Dergisi. 2005; 6(3): 7-15. 
44. Inoue T, Inoue S, Kubota K. Bactericidal Activity of Manganese and lodide lons against Staphylococcus aureus: A Possible Treatment for Acute Atopic Dermatitis. Acta Dermato. Acta Derm Venereol. 1999; 79(5): 360-362. doi: $10.1080 / 000155599750010265$.

45. Demir B, Okanlı A. Hemodiyaliz Hastalarında Gevşeme Egzersizi ve Öfke Eğitiminin Öfke İfadelerine Etkisi. Anadolu Hemşirelik ve Sağlık Bilimleri Dergisi. 2013; 16(4): 227-233.

46. Kılıç AN. (2011). Hemodiyaliz Tedavisi Alan Hastalara Uygulanan Akupres'in Kaşıntı Durumuna Etkisi. Doktora Tezi, Erciyes Üniversitesi Sağlık Bilimleri Enstitüsü Hemşirelik Anabilim Dalı (İç Hastalıkları Hemşireliği) (Danışman Nimet Karataş, Sultan Taşç1 ) Doktora Tezi, Kayseri.

47. Kökten G. (2017). Bir Üniversite Hastanesinde Polikliniğe Başvuran Cildiye Hastalarında Tamamlayıcı ve Alternatif Tıp Yöntemlerinin Kullanımı. Harran Üniversitesi Sağlık Bilimleri Enstitüsü Hemşirelik Anabilim Dalı. (Danışman Hülya Karataş) Yüksek Lisans Tezi, Şanlıurfa .

48. Dumanlı Ö, Karadeniz D, Hancı İH. Adli Hipnoz https://www.Academia.Edu/32603780/Adli_Hipnoz.Pd. Erişim tarihi:24.12.2019.

49. Shenefelt PD. Hypnosis in Dermatology. Arch Dermatol. 2000; 136(3): 393-399. doi:10.1001/Archderm.136.3.393.

50. Shenefelt PD. Use of Hypnosis, meditation, and biofeedback in dermatology. Clinics in Dermatology. 2017; 35(3): 285291. doi.org/10.1016/j.clindermatol.2017.01.007.

51. Shenefelt PD. Applying Hypnosis in Dermatology. Dermatology Nursing. 2003; 15(6): 513-7.

52. Rucklidge JJ, Saunders D. The efficacy of hypnosis in the treatment of pruritus in people with hiv/a1ds: a time-series analysis. Int J Clin Exp Hypn. 2002; 50(2): 149-169. doi.org/10.1080/00207140208410096

53. Perczel K, Gál J. Hypnotherapy of atopic dermatitis in an adult. Case report. 2016; 157(3): 111-115.DOI: 10.1556/650.2016.30312 PMID: 26929974.

54. Burrai F, Micheluzzi V, Zito PM, Pietro G, Sisti D. Effects of Live Saxophone Music on Physiological Parameters, Pain, Mood and İtching Levels in Patients Undergoing Haemodialysis. Journal of Renal Care. 2014; 40(4). doi: $10.1111 /$ Jorc. 12078 .

55. Demirtas S, Houssais C, Tanniou J, Misery L, Brenaut E. Effectiveness of a music intervention on pruritus: an open randomized prospective study; Journal of the European Academy of Dermatology and Venerology. 2019. https://doi.org/10.1111/jdv.16149.

56. Khorshid L, Yapucu Ü. Tamamlayıcı tedavilerde hemşirenin rolü. Atatürk Üniversitesi Hemşirelik Yüksekokulu Dergisi. 2005; 8(2): 124-130.

57. Akyol DS, Yildirim Y, Toker E, Yavuz B. The use of complementary and alternative medicine among chronic renal failure patients. Journal of Clinical Nursing. 2011; 20(7-8): 1035-1043 https://doi.org/10.1111/j.1365-2702.2010. 03498.x.

58. Duncan H.J. Pittman S. Govil A. Sorn L. Bissler G. Schultz T. Faith J. Kant S. Roy-Chaudhury P. Alternative Medicine Use in Dialysis Patients: Potential for Good and Bad! - Nephron Clin Pract 2007; 105: c108c113https://doi.org/10.1159/000097986

59. Markell M S. Potential Benefits of Complementary Medicine Modalities in Patients With Chronic Kidney Disease. Advances in Chronic Kidney Disease. 2005; 12(3): 292-99. 